\title{
Factors Influencing Employees to Work More and Make The Rinl Turnaround: An Experimental Study, Rinl, Visakhapatnam
}

\author{
Dr. B.S.N.Raju \\ Department of Commerce and Management Studies, \\ Maharajah’s Post-Graduate College, Phool Baugh, VIZIANAGARAM \\ Andhra Pradesh, Pin Code: 535001 \\ E-mail: bsnraju333@gmail.com
}

Received: April 19, 2011 Accepted: July 17, 2011 doi:10.5296/jmr.v3i2.638

\begin{abstract}
In any organization, management tries to coordinate various factors of production is such a way that each factors contribute to its maximum efficiency to achieve organizational goals. So far as factors like materials, technology are concerned, their efficiency largely depends upon the level of technology being used followed by the performance and motivation level of Human resources who handled and control these factors. Thus, to make total factors efficiency and effective, management has to improve the performance level of Human resources in the organization through motivation. The performance of the organization is determined by the level of ability employee to do certain work and level of motivational factors. Organization uses many techniques to motivate and utilize the talent. It should implement various strategies to make the employee to work hard.

Here the researcher has made an attempt to know the factors which influencing the employee to work more and make the RINL turnaround. To achieve the above objective, the researchers have selected Shop floor level employees and supervisors of 500 as a sample size for the study. A quota sampling technique has been used to collect the response. RINL has been providing very congenial environment to enhance the employees' competencies and achieve its strategic aims. As a result employee productivity is enhanced and cost of production is declined. The researcher observed that the rationales behind it are the commitment and motivational levels among the employee.
\end{abstract}

Keywords: Turnaround, Employee Motivation, Congenial Work Environment, Performance based Reward, Employee Participation, Quality Circles. 


\section{Introduction:}

In every organization, management tries to coordinate various factors of production is such a way that each factors contribute to its maximum efficiency to achieve organizational goals. So far as factors like materials, technology are concerned, their efficiency largely depends upon the level of technology being used followed by the performance level of Human resources who handled and control these factors. Thus, to make total factors efficiency and effective, management has to improve the performance level of Human resources in the organization through motivation. The performance of the organization is determined by the level of ability employee to do certain work and level of motivational factors.

The accomplishment of this depends on how efficiently the management is capable in encouraging their subordinates. The efficiency of management, to a large extent, depends on the willingness to do the assigned tasks with attention and passion. According to the researcher, stimulus is a method of motivating people to act to accomplish the desired targets

Generally an organization uses many techniques to motivate and utilize the talent. In this context, the organization should implement various strategies to make the employee to work hard. Sometimes, a sound practice makes them work more. These are like recognition for achievement, perks and perquisites, and opportunities for promotion, job security and congenial work environment.

\section{Literature Review}

In a study by William James C Worthy (Note 1) (1960), it was found that motivated employees worked at close to 80-90 per cent of their ability. Rina Seraphim (Note 2) (1988) compared the productivity in Private and Public Sector Units and identified the reasons for the more productivity is latent technology, work culture, high employee morale and available of capable managers. S.P.Srivatsava (Note 3) (2004) has examined that the Employee-Management relations among the Steel plants in India and observed that many factors were influencing the relations between employees and management like economic factors, psychological factors, social factors and cultural factors. He examined the management encouragement towards employee supportive schemes.

\section{Objectives}

The study objectives are to reveal the factors which motivate the employee and how these motivational factors make the employee to work more and make the organization turnaround.

\section{Methodology}

To achieve the objectives of the study the following methodology has been adopted. The volume of the data was collected by using many research instruments. However collected data was systematically developed and analyzed. Utmost care was taken in selecting the representative sample. The sample employees are working in different departments in RINL. Shop floor level employees and supervisors of 500 have been taken as a sample size for the study. 


\section{Macrothink Institute ${ }^{\mathrm{TM}}$}

Data has been collected through primary data. A structured questionnaire was prepared and canvassed to the shop floor level workers and supervisors in RINL. The questionnaire consists of both closed ended and open-ended questions, Rank Order scale is used to measure the responses from the workers at shop floor level and supervisors. Before collecting the relevant data, a pilot study was conducted for testing the questionnaire. Purely it is an experimental study and through a quota sampling, the questionnaire data is analyzed and interpreted.

\section{Analysis}

\subsection{Factors motivated the Shop floor level Workers and supervisors to work more:}

Motivation has come from motives which are the expression of human needs by a human being. In fact, the activities of employees in the organization are caused and behind every action there is particular motive or need. Table $\mathbf{1}$ indicates the factors that motivate the workers and supervisors to work more in the RINL. Here the researcher used Ranking method. A scale of eleven ranks is used. For the reason chosen as first, eleven points are given, for the reason chosen as second, ten points are given and the same descending order is followed. It is observed that 'Congenial working environment' occupied first place with 3820 points and it was ranked $1^{\text {st }}$ by $18.6 \%$ workers and supervisors, and ranked $11^{\text {th }}$ by $2.2 \%$ workers and supervisors. It is observed that 'Making job pleasant and interesting' got second place with 3435 points and it was ranked $1^{\text {st }}$ by $17.4 \%$ workers and supervisors, and ranked $11^{\text {th }}$ by $13.6 \%$ workers and supervisors. 
Table 1. Factors motivated the workers and supervisors to work more in the RINL

\begin{tabular}{|c|c|c|c|c|c|c|c|c|c|c|c|c|}
\hline & $\begin{array}{c}1^{\text {st }} \\
\text { rank }\end{array}$ & Points & $\begin{array}{c}2^{\text {nd }} \\
\text { rank } \\
\end{array}$ & Points & $\begin{array}{c}3^{\text {rd }} \\
\text { rank } \\
\end{array}$ & Points & $\begin{array}{c}4^{\text {th }} \\
\text { rank }\end{array}$ & Points & $\begin{array}{c}5^{\text {th }} \\
\text { rank }\end{array}$ & Points & $\begin{array}{c}6^{\text {th }} \\
\text { rank } \\
\end{array}$ & Points \\
\hline $\begin{array}{l}\text { Very pleasant and } \\
\text { interesting job }\end{array}$ & $\begin{array}{c}87 \\
(17.4) \\
\end{array}$ & 957 & $\begin{array}{c}85 \\
(17.0)\end{array}$ & 850 & $\begin{array}{c}46 \\
(9.2)\end{array}$ & 414 & $\begin{array}{c}30 \\
(6.0)\end{array}$ & 240 & $\begin{array}{c}80 \\
(16.0)\end{array}$ & 560 & $\begin{array}{c}18 \\
(3.6)\end{array}$ & 108 \\
\hline $\begin{array}{l}\text { Opportunities to use } \\
\text { Skills and Abilities }\end{array}$ & $\begin{array}{c}12 \\
(2.4)\end{array}$ & 132 & $\begin{array}{c}39 \\
(7.8) \\
\end{array}$ & 390 & $\begin{array}{c}19 \\
(3.8)\end{array}$ & 171 & $\begin{array}{c}49 \\
(9.8) \\
\end{array}$ & 392 & $\begin{array}{c}41 \\
(8.2)\end{array}$ & 287 & $\begin{array}{c}40 \\
(8.0) \\
\end{array}$ & 240 \\
\hline $\begin{array}{l}\text { Safety and Medical } \\
\text { facilities }\end{array}$ & $\begin{array}{c}7 \\
(1.4)\end{array}$ & 77 & $\begin{array}{c}6 \\
(1.2)\end{array}$ & 60 & $\begin{array}{c}32 \\
(6.4)\end{array}$ & 288 & $\begin{array}{c}37 \\
(7.4)\end{array}$ & 296 & $\begin{array}{c}29 \\
(5.8)\end{array}$ & 203 & $\begin{array}{c}31 \\
(6.2)\end{array}$ & 186 \\
\hline $\begin{array}{l}\text { Good support from } \\
\text { subordinates }\end{array}$ & $\begin{array}{c}39 \\
(7.8)\end{array}$ & 429 & $\begin{array}{c}24 \\
(4.8)\end{array}$ & 240 & $\begin{array}{c}54 \\
(10.8)\end{array}$ & 486 & $\begin{array}{c}29 \\
(5.8)\end{array}$ & 232 & $\begin{array}{c}25 \\
(5.0)\end{array}$ & 175 & $\begin{array}{c}26 \\
(5.2)\end{array}$ & 156 \\
\hline Promotional policies & $\begin{array}{c}28 \\
(5.8)\end{array}$ & 308 & $\begin{array}{c}44 \\
(8.8)\end{array}$ & 440 & $\begin{array}{c}29 \\
(5.8)\end{array}$ & 261 & $\begin{array}{c}39 \\
(7.8)\end{array}$ & 312 & $\begin{array}{c}43 \\
(8.6)\end{array}$ & 301 & $\begin{array}{c}66 \\
(13.2)\end{array}$ & 396 \\
\hline $\begin{array}{ll}\text { Performance } & \text { based } \\
\text { reward system } & \\
\end{array}$ & $\begin{array}{c}45 \\
(9.0)\end{array}$ & 495 & $\begin{array}{c}56 \\
(11.2)\end{array}$ & 560 & $\begin{array}{c}54 \\
(10.8) \\
\end{array}$ & 486 & $\begin{array}{c}52 \\
(10.4)\end{array}$ & 416 & $\begin{array}{c}66 \\
(13.2) \\
\end{array}$ & 462 & $\begin{array}{c}62 \\
(12.4)\end{array}$ & 372 \\
\hline Informal groups & $\begin{array}{c}54 \\
(10.8)\end{array}$ & 594 & $\begin{array}{c}42 \\
(8.4)\end{array}$ & 420 & $\begin{array}{c}55 \\
(11.0) \\
\end{array}$ & 495 & $\begin{array}{c}75 \\
(15.0)\end{array}$ & 600 & $\begin{array}{c}33 \\
(6.6)\end{array}$ & 231 & $\begin{array}{c}40 \\
(8.0)\end{array}$ & 240 \\
\hline $\begin{array}{ll}\text { Congenial } & \text { working } \\
\text { environment } & \\
\end{array}$ & $\begin{array}{c}93 \\
(18.6)\end{array}$ & 1023 & $\begin{array}{c}82 \\
(16.4)\end{array}$ & 820 & $\begin{array}{c}65 \\
(13.0)\end{array}$ & 585 & $\begin{array}{c}42 \\
(8.4)\end{array}$ & 336 & $\begin{array}{c}40 \\
(8.0)\end{array}$ & 280 & $\begin{array}{c}45 \\
(9.0)\end{array}$ & 270 \\
\hline $\begin{array}{l}\text { Good recognition to the } \\
\text { work done }\end{array}$ & $\begin{array}{c}74 \\
(14.8) \\
\end{array}$ & 814 & $\begin{array}{c}49 \\
(9.8) \\
\end{array}$ & 490 & $\begin{array}{c}39 \\
(7.8) \\
\end{array}$ & 351 & $\begin{array}{c}60 \\
(12.0) \\
\end{array}$ & 480 & $\begin{array}{r}66 \\
(13.2) \\
\end{array}$ & 462 & $\begin{array}{c}62 \\
(12.4) \\
\end{array}$ & 372 \\
\hline $\begin{array}{l}\text { Pride in working in a } \\
\text { very big PSU }\end{array}$ & $\begin{array}{c}39 \\
(7.8) \\
\end{array}$ & 429 & $\begin{array}{c}29 \\
(5.8) \\
\end{array}$ & 290 & $\begin{array}{c}42 \\
(8.4) \\
\end{array}$ & 378 & $\begin{array}{c}33 \\
(6.6) \\
\end{array}$ & 264 & $\begin{array}{c}41 \\
(8.2) \\
\end{array}$ & 287 & $\begin{array}{c}21 \\
(4.2) \\
\end{array}$ & 126 \\
\hline $\begin{array}{l}\text { Employee } \\
\text { Administrative } \\
\text { Participation }\end{array}$ & $\begin{array}{c}22 \\
(4.4)\end{array}$ & 242 & $\begin{array}{c}44 \\
(8.8)\end{array}$ & 440 & $\begin{array}{c}65 \\
(13.0)\end{array}$ & 585 & $\begin{array}{c}54 \\
(10.8)\end{array}$ & 432 & $\begin{array}{c}36 \\
(7.2)\end{array}$ & 252 & $\begin{array}{c}89 \\
(17.8)\end{array}$ & 534 \\
\hline Total & 500 & & 500 & & 500 & & 500 & & 500 & & 500 & \\
\hline
\end{tabular}

Note: A scale of eleven ranks is used. For the reason chosen as first, eleven points are given, for the reason chosen as second, ten points are given and the same descending order is followed.Figires in parenthesis are percentages to total.

(Table continued in the next page) 
Table 1(cont.). Factors motivated the Shop floor level Workers and supervisors to work more in the RINL

\begin{tabular}{|c|c|c|c|c|c|c|c|c|c|c|c|c|}
\hline & $\begin{array}{c}7^{\text {th }} \\
\text { rank }\end{array}$ & Points & $\begin{array}{c}8^{\text {th }} \\
\text { rank }\end{array}$ & Points & $\begin{array}{c}9^{\text {th }} \\
\text { rank }\end{array}$ & Points & $\begin{array}{c}10^{\text {th }} \\
\text { rank }\end{array}$ & Points & $\begin{array}{c}11^{\text {th }} \\
\text { rank }\end{array}$ & Points & $\begin{array}{c}\text { Total } \\
\text { weightage } \\
\text { points }\end{array}$ & Rank \\
\hline $\begin{array}{l}\text { Very pleasant and } \\
\text { interesting job }\end{array}$ & $\begin{array}{c}10 \\
(2.0)\end{array}$ & 50 & $\begin{array}{c}7 \\
(1.4)\end{array}$ & 28 & $\begin{array}{c}32 \\
(6.4)\end{array}$ & 96 & $\begin{array}{c}37 \\
(7.4)\end{array}$ & 64 & $\begin{array}{c}68 \\
(13.6)\end{array}$ & 68 & 3435 & 2 \\
\hline $\begin{array}{l}\text { Opportunities to } \\
\text { use Skills and } \\
\text { Abilities }\end{array}$ & $\begin{array}{c}55 \\
(11.0)\end{array}$ & 275 & $\begin{array}{c}46 \\
(9.2)\end{array}$ & 184 & $\begin{array}{c}44 \\
(8.8)\end{array}$ & 132 & $\begin{array}{c}65 \\
(13.0)\end{array}$ & 130 & $\begin{array}{c}90 \\
(18.0)\end{array}$ & 90 & 2423 & 10 \\
\hline $\begin{array}{l}\text { Safety and } \\
\text { Medical facilities }\end{array}$ & $\begin{array}{c}63 \\
(12.6)\end{array}$ & 315 & $\begin{array}{c}44 \\
(8.8)\end{array}$ & 176 & $\begin{array}{c}76 \\
(15.2)\end{array}$ & 228 & $\begin{array}{c}84 \\
(16.8)\end{array}$ & 168 & $\begin{array}{c}91 \\
(18.2)\end{array}$ & 91 & 2088 & 11 \\
\hline $\begin{array}{ll}\text { Good support } \\
\text { from all }\end{array}$ & $\begin{array}{c}56 \\
(11.2)\end{array}$ & 280 & $\begin{array}{c}82 \\
(16.4)\end{array}$ & 328 & $\begin{array}{c}51 \\
(10.2)\end{array}$ & 153 & $\begin{array}{c}51 \\
(10.2)\end{array}$ & 102 & $\begin{array}{c}63 \\
(12.6)\end{array}$ & 63 & 2644 & 8 \\
\hline $\begin{array}{l}\text { Promotional } \\
\text { policies }\end{array}$ & $\begin{array}{c}35 \\
(7.0)\end{array}$ & 175 & $\begin{array}{c}36 \\
(7.2)\end{array}$ & 144 & $\begin{array}{c}89 \\
(17.8)\end{array}$ & 267 & $\begin{array}{c}45 \\
(9.0)\end{array}$ & 90 & $\begin{array}{c}46 \\
(9.2)\end{array}$ & 46 & 2740 & 7 \\
\hline $\begin{array}{l}\text { Performance } \\
\text { based reward } \\
\text { system }\end{array}$ & $\begin{array}{c}85 \\
(17.0)\end{array}$ & 425 & $\begin{array}{c}22 \\
(4.4)\end{array}$ & 88 & $\begin{array}{c}25 \\
(5.0)\end{array}$ & 75 & $\begin{array}{c}12 \\
(2.4)\end{array}$ & 24 & $\begin{array}{c}21 \\
(4.2)\end{array}$ & 21 & 3424 & 3 \\
\hline Informal groups & $\begin{array}{c}47 \\
(9.4)\end{array}$ & 235 & $\begin{array}{c}74 \\
(14.8)\end{array}$ & 296 & $\begin{array}{c}25 \\
(5.0)\end{array}$ & 75 & $\begin{array}{c}39 \\
(7.8)\end{array}$ & 78 & $\begin{array}{c}16 \\
(3.2)\end{array}$ & 16 & 3280 & 5 \\
\hline $\begin{array}{l}\text { Congenial } \\
\text { working } \\
\text { environment }\end{array}$ & $\begin{array}{c}53 \\
(10.6)\end{array}$ & 265 & $\begin{array}{c}35 \\
(7.0)\end{array}$ & 140 & $\begin{array}{c}22 \\
(4.4)\end{array}$ & 66 & $\begin{array}{c}12 \\
(2.4)\end{array}$ & 24 & $\begin{array}{c}11 \\
(2.2)\end{array}$ & 11 & 3820 & 1 \\
\hline $\begin{array}{l}\text { Good recognition } \\
\text { to the work done }\end{array}$ & $\begin{array}{c}20 \\
(4.0)\end{array}$ & 100 & $\begin{array}{c}39 \\
(7.8)\end{array}$ & 156 & $\begin{array}{c}37 \\
(7.4)\end{array}$ & 111 & $\begin{array}{c}29 \\
(5.8)\end{array}$ & 58 & $\begin{array}{c}25 \\
(5.0)\end{array}$ & 25 & 3419 & 4 \\
\hline $\begin{array}{l}\text { Pride in working } \\
\text { in a very big PSU }\end{array}$ & $\begin{array}{c}45 \\
(9.0) \\
\end{array}$ & 225 & $\begin{array}{c}56 \\
(11.2) \\
\end{array}$ & 224 & $\begin{array}{c}64 \\
(12.8) \\
\end{array}$ & 192 & $\begin{array}{c}75 \\
(15.0) \\
\end{array}$ & 150 & $\begin{array}{c}55 \\
(11.0)\end{array}$ & 55 & 2620 & 9 \\
\hline $\begin{array}{l}\text { Employee } \\
\text { Administrative } \\
\text { Participation }\end{array}$ & $\begin{array}{c}31 \\
(6.2)\end{array}$ & 155 & $\begin{array}{c}59 \\
(11.8)\end{array}$ & 236 & $\begin{array}{c}35 \\
(7.0)\end{array}$ & 105 & $\begin{array}{c}51 \\
(10.2)\end{array}$ & 102 & $\begin{array}{c}14 \\
(2.8)\end{array}$ & 14 & 3097 & 6 \\
\hline Total & 500 & & 500 & & 500 & & 500 & & 500 & & & \\
\hline
\end{tabular}

Note: A scale of eleven ranks is used. For the reason chosen as first, eleven points are given, for the reason chosen as second, ten points are given and the same descending order is followed. Figures in parenthesis are percentages to total.

It is identified that 'Performance based reward system' was given third place with 3424 points and it was ranked $1^{\text {st }}$ by $9 \%$ workers and supervisors, and ranked $11^{\text {th }}$ by $4.2 \%$ workers and supervisors. It is to be noted that the 'good recognition to the work done' took fourth place with 3419 points and it was ranked $1^{\text {st }}$ by $14.8 \%$ workers and supervisors, and ranked $11^{\text {th }}$ by $5 \%$ workers and supervisors. 'Informal groups' occupied fifth place with 3280 points and it was ranked $1^{\text {st }}$ by $10.8 \%$ workers and supervisors, and ranked $11^{\text {th }}$ by $3.2 \%$ workers and supervisors. It is found that 'Employee Administrative Participation' was given sixth place with 3097 points and it was ranked $1^{\text {st }}$ by $4.4 \%$ workers and supervisors, and ranked $11^{\text {th }}$ by $2.8 \%$ workers and supervisors.

It is observed that 'promotion policies' occupied seventh place with 2740 points and it was ranked $1^{\text {st }}$ by $5.6 \%$ workers and supervisors and ranked $11^{\text {th }}$ by $9.2 \%$ workers and supervisors. It is found that 'good support from all' got eight place with 2644 points and it was ranked $1^{\text {st }}$ by $7.8 \%$ workers and supervisors and ranked $11^{\text {th }}$ by $12.6 \%$ workers and supervisors. It is identified that 'pride in working in a very big PSU' was given ninth place with 2620 points 
and it was ranked $1^{\text {st }}$ by $7.8 \%$ workers and supervisors and ranked $11^{\text {th }}$ by $11 \%$ workers and supervisors.

It is to be noted that the 'Opportunities to use Skills and Abilities' took tenth place with 2423 points and it was ranked $1^{\text {st }}$ by $2.4 \%$ workers and supervisors and ranked $11^{\text {th }}$ by $18 \%$ workers and supervisors. At the end the option 'Safety and Medical facilities' was given eleventh place with 2088 points and it was ranked $1^{\text {st }}$ by $5.2 \%$ workers and supervisors and ranked $11^{\text {th }}$ by $18.2 \%$ workers and supervisors.

It is identified that the employees are working at close to 90 percent of their ability. It may be said that absenteeism of employees in the RINL is low. Moreover, this also shows the reputation of the RINL.Institutional incentives also create conducive and congenial atmosphere in the organization.

\subsection{Perception of Shop floor level Workers and Supervisors on Reasons for turnaround of RINL:}

The remarkable performance on production front coupled with prudent financial management has not only resulted in achieving significant net profits but also helped the RINL emerge as a net positive company by wiping out all its accumulated losses. The RINL has received a merit certificate for its excellence in the achievement of MOU targets. It received MOU award from Dr. Man Mohan Singh, the Honorable Prime Minister of India.

Here the researcher used Ranking method. A scale of six ranks is used. For the reason chosen as first, six points are given, for the reason chosen as second, five points are given and the same descending order is followed. In the present study the researcher has identified various reasons for turnaround of the RINL. If we observe the Table 2, it is extorted that in the case of the RINL turnaround 'Positive employee attitude towards work' occupied first place with 1903 points and it was ranked $1^{\text {st }}$ by $23.8 \%$ workers and supervisors, ranked 2nd by $20.2 \%$ workers and supervisors, ranked $3^{\text {rd }}$ by $18.4 \%$ workers and supervisors, ranked $4^{\text {th }}$ by $15 \%$ workers and supervisors, ranked $5^{\text {th }}$ by $8.4 \%$ workers and supervisors and ranked $6^{\text {th }}$ by $14.2 \%$ workers and supervisors. It is identified that the reason for turnaround in the RINL 'Employee-Centered policies' got second place with 1865 points and it was ranked $1^{\text {st }}$ by $19.2 \%$ workers and supervisors, ranked $2^{\text {nd }}$ by $16.2 \%$ workers and supervisors, ranked $3^{\text {rd }}$ by $20.4 \%$ workers and supervisors, ranked $4^{\text {th }}$ by $15.6 \%$ workers and supervisors, ranked $5^{\text {th }}$ by $17.8 \%$ workers and supervisors and ranked $6^{\text {th }}$ by $10.8 \%$ workers and supervisors. 
Table 2. Perception of Shop floor level Workers and Supervisors on Reasons for turnaround of RINL

\begin{tabular}{|c|c|c|c|c|c|c|c|c|c|c|c|c|c|c|}
\hline & $\begin{array}{c}1^{\text {st }} \\
\text { rank }\end{array}$ & Points & $\begin{array}{c}2^{\text {nd }} \\
\text { rank }\end{array}$ & Points & $\begin{array}{c}3^{\text {rd }} \\
\text { rank }\end{array}$ & Points & $\begin{array}{c}4^{\text {th }} \\
\text { rank }\end{array}$ & Points & $\begin{array}{c}5^{\text {th }} \\
\text { rank }\end{array}$ & Points & $\begin{array}{c}6^{\text {th }} \\
\text { rank }\end{array}$ & Points & $\begin{array}{c}\text { Total } \\
\text { weightage } \\
\text { points } \\
\end{array}$ & Rank \\
\hline $\begin{array}{l}\text { Professionalism in } \\
\text { Management }\end{array}$ & $\begin{array}{c}94 \\
(19.8)\end{array}$ & 564 & $\begin{array}{c}92 \\
(19.4)\end{array}$ & 460 & $\begin{array}{c}66 \\
(13.2)\end{array}$ & 264 & $\begin{array}{c}86 \\
(17.2)\end{array}$ & 258 & $\begin{array}{c}94 \\
(18.8)\end{array}$ & 184 & $\begin{array}{c}68 \\
(13.6)\end{array}$ & 68 & 1798 & 4 \\
\hline $\begin{array}{l}\text { Employee-Centered } \\
\text { policies }\end{array}$ & $\begin{array}{c}96 \\
(19.2)\end{array}$ & 576 & $\begin{array}{c}81 \\
(16.2)\end{array}$ & 405 & $\begin{array}{c}102 \\
(20.4)\end{array}$ & 408 & $\begin{array}{c}78 \\
(15.8)\end{array}$ & 234 & $\begin{array}{c}89 \\
(17.8)\end{array}$ & 188 & $\begin{array}{c}54 \\
(10.8)\end{array}$ & 54 & 1865 & 2 \\
\hline $\begin{array}{lr}\begin{array}{l}\text { Positive } \\
\text { attitude }\end{array} & \text { towards } \\
\text { work } & \\
\end{array}$ & $\begin{array}{c}119 \\
(23.8)\end{array}$ & 714 & $\begin{array}{c}101 \\
(20.2)\end{array}$ & 505 & $\begin{array}{c}92 \\
(18.4)\end{array}$ & 368 & $\begin{array}{c}75 \\
(15.0)\end{array}$ & 225 & $\begin{array}{c}42 \\
(8.4)\end{array}$ & 84 & $\begin{array}{c}71 \\
(14.2)\end{array}$ & 71 & 1903 & 1 \\
\hline Reduction in Duties & $\begin{array}{c}26 \\
(5.2)\end{array}$ & 156 & $\begin{array}{c}64 \\
(12.8)\end{array}$ & 320 & $\begin{array}{c}79 \\
(15.8)\end{array}$ & 316 & $\begin{array}{c}121 \\
(24.2)\end{array}$ & 363 & $\begin{array}{c}103 \\
(20.6)\end{array}$ & 206 & $\begin{array}{c}107 \\
(21.4)\end{array}$ & 107 & 1468 & 6 \\
\hline $\begin{array}{l}\text { Global Competition } \\
\text { in Steel Industry }\end{array}$ & $\begin{array}{c}121 \\
(24.2)\end{array}$ & 726 & $\begin{array}{c}99 \\
(19.8)\end{array}$ & 495 & $\begin{array}{c}69 \\
(13.8)\end{array}$ & 276 & $\begin{array}{c}18 \\
(3.6)\end{array}$ & 54 & $\begin{array}{c}81 \\
(16.2)\end{array}$ & 162 & $\begin{array}{c}112 \\
(22.4)\end{array}$ & 112 & 1825 & 3 \\
\hline $\begin{array}{l}\text { Rise in domestic } \\
\text { and international } \\
\text { demand for steel }\end{array}$ & $\begin{array}{c}44 \\
(8.8)\end{array}$ & 264 & $\begin{array}{c}63 \\
(12.6)\end{array}$ & 315 & $\begin{array}{c}92 \\
(18.4)\end{array}$ & 368 & $\begin{array}{c}122 \\
(24.4)\end{array}$ & 366 & $\begin{array}{c}91 \\
(18.2)\end{array}$ & 182 & $\begin{array}{c}88 \\
(17.6)\end{array}$ & 88 & 1583 & 5 \\
\hline Total & 500 & & 500 & & 500 & & 500 & & 500 & & 500 & & & \\
\hline
\end{tabular}

Note: A scale of six ranks is used. For the reason chosen as first six points are given for the reason chosen as second five points are given and the same descending order is followed. Figures in parenthesis are percentages to total.

'Global Competition in Steel Industry' stood at third place with 1825 points and it was ranked $1^{\text {st }}$ by $24.2 \%$ workers and supervisors, ranked $2^{\text {nd }}$ by $19.8 \%$ workers and supervisors, ranked $3^{\text {rd }}$ by $13.8 \%$ workers and supervisors, ranked $4^{\text {th }}$ by $3.6 \%$ workers and supervisors, ranked $5^{\text {th }}$ by $16.2 \%$ workers and supervisors and ranked $6^{\text {th }}$ by $22.4 \%$ workers and supervisors.

It is observed that in the case of option of turnaround in the RINL 'Professionalism in Management' was given fourth place with 1798 points and it was ranked $1^{\text {st }}$ by $18.8 \%$ workers and supervisors, ranked $2^{\text {nd }}$ by $18.4 \%$ workers and supervisors, ranked $3^{\text {rd }}$ by $13.2 \%$ workers and supervisors, ranked $4^{\text {th }}$ by $17.2 \%$ workers and supervisors, ranked $5^{\text {th }}$ by $18.8 \%$ workers and supervisors and ranked $6^{\text {th }}$ by $13.6 \%$ workers and supervisors.

It is observed that the reasons for turnaround in the RINL as 'Rise in domestic and international demand for steel' got fifth place with 1583 points and it was ranked $1^{\text {st }}$ by $8.8 \%$ workers and supervisors, ranked $2^{\text {nd }}$ by $12.6 \%$ workers and supervisors, ranked $3^{\text {rd }}$ by $18.4 \%$ workers and supervisors ranked $4^{\text {th }}$ by $24.4 \%$ workers and supervisors, ranked $5^{\text {th }}$ by $18.2 \%$ workers and supervisors and ranked $6^{\text {th }}$ by $17.6 \%$ workers and supervisors. Finally it is observed that among the reasons for turnaround in the RINL 'Reduction in Duties' secured sixth place with 1468 points and it was ranked $1^{\text {st }}$ by $5.2 \%$ workers and supervisors, ranked $2^{\text {nd }}$ by $12.8 \%$ workers and supervisors, ranked $3^{\text {rd }}$ by $15.8 \%$ workers and supervisors, ranked $4^{\text {th }}$ by $24.4 \%$ workers and supervisors ranked $5^{\text {th }}$ by $20.6 \%$ workers and supervisors and ranked $6^{\text {th }}$ by $21.4 \%$ workers and supervisors. 
In fact, the RINL has taken up a number of measures to turnaround. It has provided several incentives to the work-force so that they work hard to enhance the productivity. Thus, the organization has developed productive work culture, emotional binding with the organization, Quality Circles, missionary zeal and recreational facilities to work more and as a result there is drastic improvement in the productivity. At the same time the firm sales and profitability are also increased.

\section{Conclusion}

Here the researcher has identified that no single factor is the cause for the turnaround of RINL. A number of factors influenced them in boosting the turnover and the growth of RINL. Almost every worker, supervisor, and management played a key role in the turnaround of the RINL and to make it a world class integrated steel plant.

\section{References}

Ashok Mittal. (2009). Steel: Signs of Revival, Chartered Financial Analyst: The Analysist, ICFAI University Press, November, 2009.

B P Gavaghan. (1998). Revolutionary Leadership. Optimizing People and Markets.. Iron and Steel Maker, vol 28, no 5, May 1998, pp 75-76.

Beach, D.S. (1977). Personnel: The Management of People at Work.

Breckenridge. (2008). The Plain Dealer: Productivity in a Indian Paradise, The Analysist, ICFAI University Press, Kolkota.

Competitiveness of global steel industry, (2008). The Wall Street Journal, October, 25.

D’Costa, Anthony. (1999). The Global Restructuring of the Steel Industry, Routledge, London and New York.

Edward E.Lawyer III. (2000). Rewarding Excellence pay for Strategies for the New Economy, Jossey-BassInc, California, Dec,2000.

H Wiesingh. (2000).At the Frontiers of Technology. Iron and Steel Maker, vol 27, no 1, January 2000, pp 47-48.

Kaplan, Robert S and Norton, David P. (2000). Having Trouble with your Strategy Then map it, Harvard Business Review, 78(5), September-October, 167-176.

Kumar Satyaki and Ranjit Goswami. (2008). Case Studies on Global Steel Industry: Getting Bigger and Better, ICFAI Business School research Centre, Kolkota, 2008.

M E Porter. (1980). Competitive Strategy: Techniques for Analyzing Industries and Competitors. The Free Press, New York, 1980, pp 129-130.

National Council of Applied Economic Research (NCAER). (2008). Competitiveness of Indian Steel Industry, New Delhi.

P N Khandelwalla. (2005). Innovative Corporate Turnaround. Sage Publication, New Delhi. 
R.C.Sexana. (2005). Labour Problems in steel industry, K.Nath \& Co, Meerut.

Rosen, Benson \& Thomas H. Jerdel. (2005). Organization Policies for the New Century, Human Resource Management, Fall.

S G Dastidar. (2001). Reforms and Restructuring in Global Steel. Iron and Steel Review, December 2001, pp 13-15.

Shank, John K and Govindarajan, Vijay. (1992). Strategic Cost Management and the value chain, Journal of Cost Management, Winter, 5-21.

Turnaround and Transformation: Path to Global Competitiveness. (1999). Steel Authority of India Limited, September 1, 1999, pp 11-13.

\section{Notes}

Note 1. William James C Worthy, "Factors influencing Employee Morale”, Harvard Business Review, 28 (1), Jan, 1960, pp. 61-73.

Note 2. Miss. Rina Seraphim, Productivity in iron and steel industry in India: A Management Perspective, Faculty of economics, Patna University, Patna, 1988,p-62.

Note 3. Mr. S.P.Srivatsava, Labour -Management relations in steel plants in India, Lucknow,2004,p-223. 